\title{
Carcinoma of the Lacrimal Gland pM1 TNM Finding v7
}

National Cancer Institute

\section{Source}

National Cancer Institute. Carcinoma of the Lacrimal Gland pM1 TNM Finding v7. NCI

Thesaurus. Code C88803.

Carcinoma of the lacrimal gland with distant metastasis. (from AJCC 7th Ed.) 